Gunji, J. S. Hsia, Marvin I. Knopp, Erik A. Lippa, Kenneth B. Stolarsky and Peter J. Weinberger. Professor Philip Dwinger of the University of Illinois at Chicago Circle organized a special session on Lattice Theory; the speakers were M. E. Adams, Raymond Balbes, Mary Katherine Bennett, Stephen D. Comer, Alan Day, George Epstein, David Kelly and G. T. Rüttiman. Professor Paul Fong of the University of Illinois at Chicago Circle organized a special session on Finite Groups; the speakers were I. Martin Isaacs, Ernest E. Shult, Louis Solomon, Bhama Srinivasan, Betty Salzberg Stark, Michio Suzuki and John H. Walter. Professor Saunders Mac Lane of the University of Chicago organized a special session on Category Theory; the speakers were Radu Diaconescu, Peter T. Johnstone, Dana May Latch, F. William Lawvere, John L. Mac Donald, Michael Makkai, Robert Paré and Donovan H. Van Osdol. Professor Mark A. Pinsky of Northwestern University organized a special session on Stochastic Analysis; the speakers were Thomas C. Gard, F. Alberto Grünbaum, Thomas G. Kurtz, George C. Papanicolaou, Mark A. Pinsky, Walter A. Rosenkrantz, Thomas H. Savits and Daniel W. Stroock. Professor R. Clark Robinson of Northwestern University organized a special session on Global Analysis; the speakers were Steve Batterson, Louis S. Block, Robert L. Devaney, Brian H. Marcus, Richard P. McGehee, Julian I. Palmore III, Dennis G. Pixton, William J. Satzer and Carl P. Simon. Professor Paul J. Sally, Jr. of the University of Chicago organized a special session on Harmonic Analysis on Locally Compact Groups; the speakers were Dan Barbasch, Stephen S. Gelbart, Philip C. Kutzko, Mark E. Novodorsky, Richard C. Penney, R. Ranga Rao, Diana F. Shelstad and Norman D. Winarsky. Professor Philip D. Wagreich of the University of Illinois at Chicago Circle organized a special session on Algebraic Geometry; the speakers were Eric M. Friedlander, Gerald L. Gordon, Tsuong-Tsieng Moh, M. Pavaman Murthy, Peter P. Orlik, Richard C. Randell, Tatsuo Suwa and John W. Wood.

There were three sessions of contributed ten-minute papers, in which a total of 16 papers were actually presented. The presiding officers were Melvin L. Heard, Richard G. Larson and Neil W. Rickert.

URBANA, ILLINOIS

Paul T. Bateman Associate Secretary

\title{
THE NOVEMBER MEETING IN BLACKSBURG
}

The seven hundred twenty-ninth meeting of the American Mathematical Society was held at the Virginia Polytechnic Institute and State University on Friday and Saturday, November 7-8, 1975. There were 225 members of the Society registered.

By invitation of the Committee to Select Hour Speakers for Southeastern Sectional Meetings there were three invited speakers. Professor Lida Barrett introduced R. D. Daverman of the University of Tennessee at Knoxville 
who spoke on Embeddings of $(n-1)$-spheres in $n$-space. Professor J. A. Cima introduced Professor James D. Buckholtz of the University of Kentucky who spoke on Strong convergence and polynomial expansions of analytic functions. Professor D. R. McMillan introduced Professor William Jaco of Rice University who spoke on 3-manifold groups-A survey.

By invitation of the same committee there were three special sessions organized by Professors R. Hodel, Eugene M. Norris and John Burns, respectively.

There were six sessions for contributed papers which were chaired by Professors Jimmy Arnold, R. Dickman, William Greenberg, Douglas L. Casta, J. A. Cochran and R. McCoy.

There was a beer party held on Friday evening from 8:00 p.m. until midnight for members of the Society and their guests.

TAllahassee, Florida

O. G. HARRold

Associate Secretary

\section{THE NOVEMBER MEETING IN LOS ANGELES}

The seven hundred thirtieth meeting of the American Mathematical Society was held at the University of California, Los Angeles, California, on Saturday, November 15, 1975. There were 134 registrants including 115 members of the Society. There was also a concurrent meeting of the Association for Women in Mathematics.

By invitation of the Committee to Select Hour Speakers for Far Western Sectional Meetings, there were two invited hour addresses. Professor Robert Osserman, Stanford University, lectured on The isoperimetric inequality; he was introduced by Professor Nathaniel Grossman. Professor Jerry L. Kazdan, University of California, Berkeley and University of Pennsylvania, spoke on Applications of partial differential equations to differential geometry. Professor James H. White introduced Professor Kazdan.

There were two special sessions of selected twenty-minute papers. Professor Theodore W. Gamelin of the University of California, Los Angeles, organized a special session on Function Algebras and Related Areas. The speakers were Alice Chang, Irving L. Glicksberg, Donald E. Marshall, Donald E. Sarason, David A. Stegenga, Joseph L. Taylor, and James Li-Ming Wang. Professor Nathaniel Grossman of the University of California, Los Angeles, organized a special session on Differential Geometry. The speakers were John T. Burns, James B. Carrell, Mark Green, Stefan Hildebrandt, William Meeks, and Joel L. Weiner.

There were two sessions of contributed ten-minute papers chaired by Professors Charles W. Austin and Garry D. Hart.

Eugene, OREgon

Kenneth A. Ross Associate Secretary 